Article

\title{
Assessing Cultural Heritage Adaptive Reuse Practices: Multi-Scale Challenges and Solutions in Rijeka
}

\author{
Nadia Pintossi ${ }^{1, *(D)}$, Deniz Ikiz Kaya ${ }^{1}$ (D) and Ana Pereira Roders ${ }^{2}$ (D) \\ 1 Department of the Built Environment, Eindhoven University of Technology, \\ 5600 MB Eindhoven, The Netherlands; d.ikiz.kaya@tue.nl \\ 2 Department of Architectural Engineering and Technology, Delft University of Technology, \\ 2628 BL Delft, The Netherlands; A.R.Pereira-Roders@tudelft.nl \\ * Correspondence: n.pintossi@tue.nl
}

Citation: Pintossi, N.; Ikiz Kaya, D.; Pereira Roders, A. Assessing Cultural Heritage Adaptive Reuse Practices: Multi-Scale Challenges and Solutions in Rijeka. Sustainability 2021, 13, 3603 https://doi.org/10.3390/su13073603

Academic Editor: Christian Ost

Received: 5 February 2021

Accepted: 18 March 2021

Published: 24 March 2021

Publisher's Note: MDPI stays neutral with regard to jurisdictional claims in published maps and institutional affiliations.

Copyright: (c) 2021 by the authors. Licensee MDPI, Basel, Switzerland. This article is an open access article distributed under the terms and conditions of the Creative Commons Attribution (CC BY) license (https:// creativecommons.org/licenses/by/ $4.0 /)$.

\begin{abstract}
Cultural heritage is recognized as a driver and enabler for sustainable development, and its role within the circular economy and circular cities is gaining attention. Its adaptive reuse plays a significant role in this while prolonging the heritage lifespan, preserving the values associated with heritage assets, and creating shared values. The adoption and implementation of the adaptive reuse of cultural heritage practices present challenges at multiple levels. This research aims to identify these challenges and propose solutions to overcome them, considering the post-industrial port city of Rijeka, Croatia, as a case study. The adaptive reuse of cultural heritage practices was assessed through a stakeholder engagement workshop performing a multi-scale analysis using the Historic Urban Landscape approach as an assessment framework. Forty-nine themes were identified by content analysis of the challenges and solutions identified by stakeholders involved in adaptive reuse practices and decision-making in the city. The five most mentioned themes refer to aspects relating to participation, capacity, regulatory systems, economics-finance, and knowledge. These findings provide evidence of challenges for policy- and decision-makers to be addressed in policy-making. Solutions are also suggested to facilitate the adaptive reuse of cultural heritage in the city of Rijeka and similar contexts, such as introducing policies to support participatory decision-making whose absence is a barrier.
\end{abstract}

Keywords: adaptive reuse; challenge assessment; city of Rijeka; circular city; circular economy; cultural heritage; historic urban landscape approach; solution identification; stakeholder engagement

\section{Introduction}

Resource scarcity, rapid urbanization, and climate change threaten ecosystems and human wellbeing. These threats challenge the livability of human settlements [1,2]. To tackle these threats, sustainable development [3] and a transition toward a circular economy are seen as crucial $[4,5]$-the circular economy includes processes of production and consumption that minimize environmental impacts and waste production by extending the lifespan and reducing the consumption and waste of products and materials [6], while "creating environmental quality, economic prosperity and social equity, to the benefit of current and future generations" [7] (p. 225). Furthermore, to address the threats posed by resource scarcity, rapid urbanization, and climate change, the built environment is a key sector to act on. In fact, the built environment consumes about half of the materials extracted every year, and it is responsible for nearly $40 \%$ of energy-related carbon dioxide $\left(\mathrm{CO}_{2}\right)$ emissions $[4,8]$.

Within the built environment, cultural heritage is receiving attention because it is recognized as a driver and enabler for sustainable development [1,9-11] and a key to ensure urban livability [12,13]. Cultural heritage consists of nonrenewable resources inherited from past generations that express people's values, knowledge, and traditions [14]. Over time, heritage broadens from the concept of "monument"-object-based, top-down, static, and prescriptive-to "cultural heritage"-process-based, also bottom-up, dynamic, 
and an expression of values and "social choice" [15-20]. Along this evolution, the intangible dimension of heritage gained recognition and the range of categories of heritage expanded [19,21]. For these reasons, "cultural heritage" is preferred here to "built heritage." This choice of terminology avoids the limitation of the investigation to narrower possible definitions of built heritage that disregard its intangible dimension [18]. Reflecting the expansion of the concept of cultural heritage, heritage management shifted toward being understood as a "management of change" [16,22], opening up to a wider variety of stakeholders and disciplines [23], and recognizing a plurality of heritage practices and approaches $[19,24,25]$. Particularly, Bullen and Love pointed out that the role of conservation has shifted from preservation toward "being part of a broader strategy for urban regeneration and sustainability," which demands a broad participation and interdisciplinarity [26] (p. 411). Hence, conserving both tangible and intangible heritage plays a role in sustainable development [27-30].

In parallel to sustainable development, the role of cultural heritage within the circular economy is gaining attention. Particularly, its adaptive reuse is regarded as "the entry point for implementing the circular city," i.e., "the spatial/territorial aspects of circular economy" [31] (p. 245). Adaptive reuse of cultural heritage is defined as the process that conserves heritage by providing the site/building with a new function [26,32]. Thus, the adaptive reuse extends the life cycle of heritage $[33,34]$. This extension aligns with the circular economy goal of reducing environmental impacts by reusing resources over time $[35,36]$. Furthermore, the adaptive reuse of cultural heritage can implement circular models in its management, such as circular business and governance models [34,37-39], and include nature-based solutions, e.g., rainwater reuse [34].

Previous research has found that the adaptive reuse of cultural heritage can contribute to sustainable development $[40,41]$. This contribution is due to its environmental [34,42,43], social [44-47], cultural [32,44], and economic [26,42] benefits when negative impacts, such as unplanned gentrification, are averted [48]. Examples of these benefits are conserving the embodied energy, bypassing the waste production associated with demolition $[29,43]$, and retaining tangible and intangible values of cultural heritage $[24,44,49]$. Besides these benefits, at the local level, the adaptive reuse of cultural heritage can promote climate change mitigation within the built environment by integrating climate mitigation and adaptation strategies [32,34,50]. Due to these benefits, the adaptive reuse of cultural heritage can contribute to the achieving of sustainable development and circular cities [31,44,48,51,52].

Even though previous research has indeed identified the potential of the adaptive reuse of cultural heritage for sustainable development, it has also found that these reuse practices face several challenges [29,32,53,54]. Here, "challenges" are understood as all the factors hampering these heritage reuse processes, i.e., negative factors including barriers, obstacles, and constraints. Previous studies identified the challenges to the adaptive reuse of cultural heritage, mainly from the perspective of architects and project managers (Table 1). Overall, these challenges can be categorized as "compliance with codes and regulations" and "current design requirements" [32] (p. 508). 
Table 1. Challenges to the adaptive reuse of cultural heritage as defined in the literature.

\begin{tabular}{lc}
\multicolumn{1}{c}{ Challenge } & Reference \\
\hline Availability of reliable information & {$[32]$} \\
Availability of skilled tradesmen and compatible materials & {$[26,32,55]$} \\
Compliance with codes and regulation requirements & {$[32,55]$} \\
Conflict with the local community about the new uses of the heritage & {$[56]$} \\
"Continuity of local community life" & {$[29]$} \\
Effective and appropriate community engagement opportunities & {$[29]$} \\
Economic viability and costs & {$[29,57-59]$} \\
Handling of contaminations and hazardous materials & {$[58,60-62]$} \\
Identification of the new function & {$[48]$} \\
Minimization of change & {$[29,57,63]$} \\
Obtainment of the approval of the change of use & {$[32,56,64,65]$} \\
"Physical restrictions" (e.g., the structural grid) & {$[32,48,63]$} \\
Political circumstances & {$[66,67]$} \\
Prevention of values loss & {$[29,57,63]$} \\
Status of physical decay & {$[68,69]$} \\
Stigma associated with the building/site/area & {$[70] 1$} \\
\hline
\end{tabular}

${ }^{1}$ Discussing adaptation of buildings in general without focusing on heritage reuse.

Yet, in identifying the challenges faced by the adaptive reuse of cultural heritage, three aspects were not included: The variety of stakeholders, the influences among scales, and the relationship between heritage and its context. First, most of the published research up to now has consulted architects and project managers. However, it has also been highlighted in the literature that these reuse practices are multidisciplinary [48] and involve a broad spectrum of stakeholders, including owners, building managers, developers, heritage consultants, local authorities, citizens, investors, among others [26,57,69,71]. This limitation of stakeholders in past research indicates the need to engage a broad variety of actors in identifying these challenges [32]. Thus, it can be assumed that a multi-stakeholder perspective may result in a wider range of recognized issues, reflecting the plurality of experiences and perspectives considered, which is limited in the literature. Second, research on the adaptive reuse of cultural heritage has identified challenges focusing on the site-scale, i.e., buildings and areas. Nevertheless, measures taken on other scales also impact the site, and adaptive reuse is not limited to individual sites [72,73]. Therefore, challenges to the adaptive reuse of cultural heritage might also be found at higher levels, such as the urban scale. Third, it is important to consider the relationships existing between heritage and its context [24] and to acknowledge the need for a holistic approach in heritage conservation [22,74]. Limitations in the stakeholders involved and the scales considered suggest the need for further research on factors hampering the adaptive reuse of cultural heritage.

This research, therefore, aims to identify the challenges to the adaptive reuse of cultural heritage including these three aspects. In particular, it aims to identify these challenges by engaging a broad variety of stakeholders, considering a multi-scale perspective, and using the Historic Urban Landscape approach as a framework for the identification. For this identification, a case study, i.e., the port city of Rijeka, is analyzed. This European post-industrial city is re-developing into a cultural city and urban tourist destination by implementing an urban regeneration program focusing on heritage conservation and adaptive reuse. Hence, this study answers the following research question: What are the challenges to cultural heritage adaptive reuse identified by stakeholders at the urban and site scale in the port city of Rijeka? This identification offers insights into the challenges to practitioners, policyand decision-makers, and other actors dealing with the adaptive reuse of cultural heritage. Therefore, this research raises awareness of the factors hampering the adaptive reuse of cultural heritage. Furthermore, solutions to overcome these barriers are also offered. Identifying these challenges is the first step to facilitate these reuse practices, which promote sustainable development and constitute the entry point for circular cities [26,31]. 


\section{Materials and Methods}

This study identified challenges to cultural heritage adaptive reuse and solutions to overcome these challenges at multiple scales in the case study of Rijeka. The factors hampering heritage reuse were derived by content analysis of the data collected through a stakeholder engagement workshop. Here, "stakeholder participation" refers to the process of involving the broad variety of actors of heritage reuse in producing the knowledge that informs the data collection. However, participation is mentioned in the results as the various processes of stakeholder collaboration $[75,76]$ in the adaptive reuse of cultural heritage. This second meaning encompasses the varying degrees of democratic participation in the decision-making $[14,76,77]$.

\subsection{Participants}

Thirty-five stakeholders (hereafter participants) participated in the study. They were selected by purposeful sampling $[32,78,79]$ to engage relevant stakeholders in identifying the challenges encountered in the adaptive reuse of cultural heritage and solutions. As the adaptive reuse of cultural heritage is a multi-disciplinary [48] and multi-actor $[32,80,81]$ practice-interlinked with heritage, urbanism, and sustainable development-the participants were sampled among stakeholders from the public, private, knowledge, and NGO sector and experienced in adaptive reuse, heritage conservation and management, circular cities, and sustainable urban development fields within Rijeka or Europe. The participants were representatives of (i) the Municipality of Rijeka with expertise in energetic renovation and entrepreneurship development; (ii) the Port Authority of Rijeka managing the industrial heritage building of the docks; (iii) the Natural History Museum of Rijeka, hosted in a reused villa and castle; (iv) the Rijeka2020 Agency engaged in reusing several heritage sites on occasions of the year as the European Capital of Culture; (v) the tourist board; (vi) cultural associations and institutions, e.g., CTK Rijeka; (vii) an architecture firm; (viii) a consulting firm for urban regeneration; (ix) a waste management company; and $(x)$ researchers, NGOs, and local/regional authorities involved in the CLIC project. Hence, this variety of participants allows the engagement of a broader range of actors in identifying these challenges. Considering these other views better reflects the spectrum of heritage reuse stakeholders and addresses their limited variety in previous identifications, as also highlighted by Conejos and co-workers [32].

The Municipality of Rijeka-the local partner in organizing the workshop-invited the stakeholders. The stakeholders that accepted the invitation voluntarily took part in the workshop and received the informed consent form used by the CLIC project, the EU funded Horizon2020 project framing this study. Furthermore, the data collected were anonymous.

\subsection{Framework for the Identification of Challenges of Cultural Heritage Adaptive Reuse}

To identify the challenges, the participants were provided with a framework guiding them in scrutinizing the adaptive reuse of cultural heritage. In other words, participants used a framework to assess heritage reuse practices and identify their challenges, hereafter "identification" or "assessment framework". This framework was based on the Historic Urban Landscape (HUL) approach and a multi-scale perspective.

\subsubsection{Historic Urban Landscape Approach}

To identify challenges, the participants' assessment of the adaptive reuse of cultural heritage was framed by the six steps of the HUL approach, hereafter HUL steps (Table 1). The UNESCO Recommendation on the Historic Urban Landscape proposed a holistic and integrated approach to heritage conservation and management [21,22]. Thus, the HUL approach considers the wider urban context without being limited to the heritage site, it adopts an interdisciplinary perspective, and it recognizes the complexity and layering of the landscape [74]. This approach acknowledges the need to integrate conservation in the wider goal of sustainable urban development and vice versa and manages "thoughtful change" [74] (p. 3). At the local level, the HUL steps (Table 2) guided the establishment of 
several action plans for heritage conservation and management [82], e.g., a workshop in Zanzibar to identify actions to integrate conservation and planning [83]. Hence, they can be adopted as a framework to analyze conservation processes. As the adaptive reuse is a strategy to conserve cultural heritage, the HUL steps were selected to frame the assessment of this process to identify its challenges.

Table 2. Identification framework: The six Historic Urban Landscape (HUL) steps.

\begin{tabular}{ll}
\hline \multicolumn{1}{c}{ Short Name } & \multicolumn{1}{c}{ HUL Step Description ${ }^{1}$} \\
\hline Mapping & Mapping natural, cultural, and human resources \\
Consensus & Reaching a consensus on what values and related attributes to protect \\
Vulnerability & Assessing the vulnerability of the identified values and related attributes to change and development \\
Integrate & Integrating values, related attributes, and their vulnerability in urban development framework \\
$\begin{array}{l}\text { Prioritize or Prioritization } \\
\text { Partnership }\end{array}$ & $\begin{array}{l}\text { Prioritizing actions for conservation and development } \\
\text { Establishing local partnerships and management frameworks for each of the actions }\end{array}$ \\
\hline
\end{tabular}

\subsubsection{Multi-Scale and Case Study}

The identification of challenges to the adaptive reuse of cultural heritage considered multiple scales: Site scale, the urban scale, and "elsewhere". This multiscalar perspective was adopted to include the impacts of measures and practices at various levels that influence adaptive reuse $[72,87]$. The scale "elsewhere" signified scales wider than the urban level, e.g., national, or contexts for knowledge transfer. The participants were asked to further specify this scale [88].

For the site scale, the RiHub building was selected for the case study. It is a multifunctional space that serves as the information center for the Rijeka European Capital of Culture 2020, operational center for the Rijeka 2020 Agency, and venue for the participatory programs [89-92]. It also hosts a co-working space for professionals active in the cultural and creative sector, the first of the city [89,93]. The historic building was designed by Luigi Luppis, prominent architect in Rijeka, and it is an example of Art Nouveau architecture in the city $[94,95]$. It was built at the beginning of the 20th century as the first nursery of the city and for housing. After the nursery was closed, several commercial activities followed one another until, in 2018, RiHub was inaugurated $[89,90,95]$. The building is currently owned by the Municipality of Rijeka [95]. RiHub was selected as the site case because (i) of its historic and architectural values; (ii) part of the space will need a new function, once the program of Rijeka European Capital of Culture is concluded [96]; and (iii) it received the Croatian Architects' Association "Bernardo Bernardi" award for the interior design [97].

The urban level considered the city of Rijeka as a whole. This post-industrial port city, located in the Northeast Adriatic, is the third Croatian city and the principal port of the country. Its urban landscape includes a medieval core and the developments of the 19th and 20th centuries [98-100]. In the 19th and 20th centuries, the port and the industry activities drove the growth of the city until it was halted by the Croatian War of Independence and the consequential political and economic changes. Several industries were closed, and the port activity was downsized, leaving the city of Rijeka to adapt to the mutated conditions $[100,101]$. This city was chosen as a case study as it is an example of a European post-industrial city with a vast heritage, and an urban regeneration strategy focusing on heritage conservation as part of its plan to develop into a cultural city and urban tourist destination [98,101-104].

\subsection{Data Collection: The Historic Urban Landscape (HUL) Workshop}

Focus groups were employed for the data collection that was performed during the HUL workshop, held in Rijeka in March 2019, within the CLIC project-Circular models leveraging investments in Cultural Heritage Adaptive Reuse. This method was chosen because it is a participatory method that "collects data through group interaction on a topic determined by the researcher" [105] (p. 130). Focus groups were selected as the data collec- 
tion method because they allow the harvest of information based on group intelligence and entails mutual learning [106]. On the one hand, participants also benefit from joining the workshop. On the other hand, the research benefits from the data validation by consensus, and from the interaction among participants that stimulates their reflection [107]. Furthermore, as Landorf points out, "stakeholder participation offers a mechanism to gain a holistic understanding of a social problem" [30] (p. 496). The workshop was structured as a series of six sessions of parallel focus groups.

In multidisciplinary teams, participants identified challenges and proposed solutions in six sessions of parallel focus groups. The workshop started with a plenary session introducing and explaining the research activity. In other words, participants were presented with the framework for the identification of challenges of cultural heritage adaptive reuse and the structure of the workshop. The aim was clarified, i.e., identifying challenges to the adaptive reuse of cultural heritage in Rijeka at multiple scales and proposing solutions to tackle these issues. In the room, there were six tables with six chairs each. Every table was dedicated to a specific HUL step and had an assigned facilitator. At the start of each session, participants joined one of the tables. As they were asked to try to avoid sitting with representatives of the same organization or project, this ensured multi-disciplinary and multi-stakeholder discussions. Once a table was joined, participants identified challenges to cultural heritage adaptive reuse, focusing on the multiple scales considered and the HUL step addressed at that table. Each focus group session was structured in three phases and lasted 20 minutes. First, the facilitator re-introduced the HUL step framing the identification. Second, the participants had a few minutes to individually identify the challenges and gather their own thoughts. Finally, the facilitated roundtable discussion took place and the group collectively identified the challenges and proposed solutions. The facilitators took notes reporting the contributions made by the participants. Afterward, participants joined another table. The contributions were agreed and validated by consensus among the participants, and they constitute the data analyzed in this study.

\subsection{Data Analysis}

To analyze the data set, content analysis techniques were employed [108]. Prior to the analysis, the corpus was prepared [109] by translation and transcription of the contributions, removal of abbreviations, and exclusion of ambiguous wording. The contributions that could be identified neither as challenges nor as solutions $(n=2)$ by the authors were also removed from the sample. A manifest analysis [110] was conducted on the prepared corpus, including both inductive and deductive coding, resulting in a frequency and thematic synthesis (Figure 1) [108,110,111]. This coding was validated by peer-debriefing [112]. 


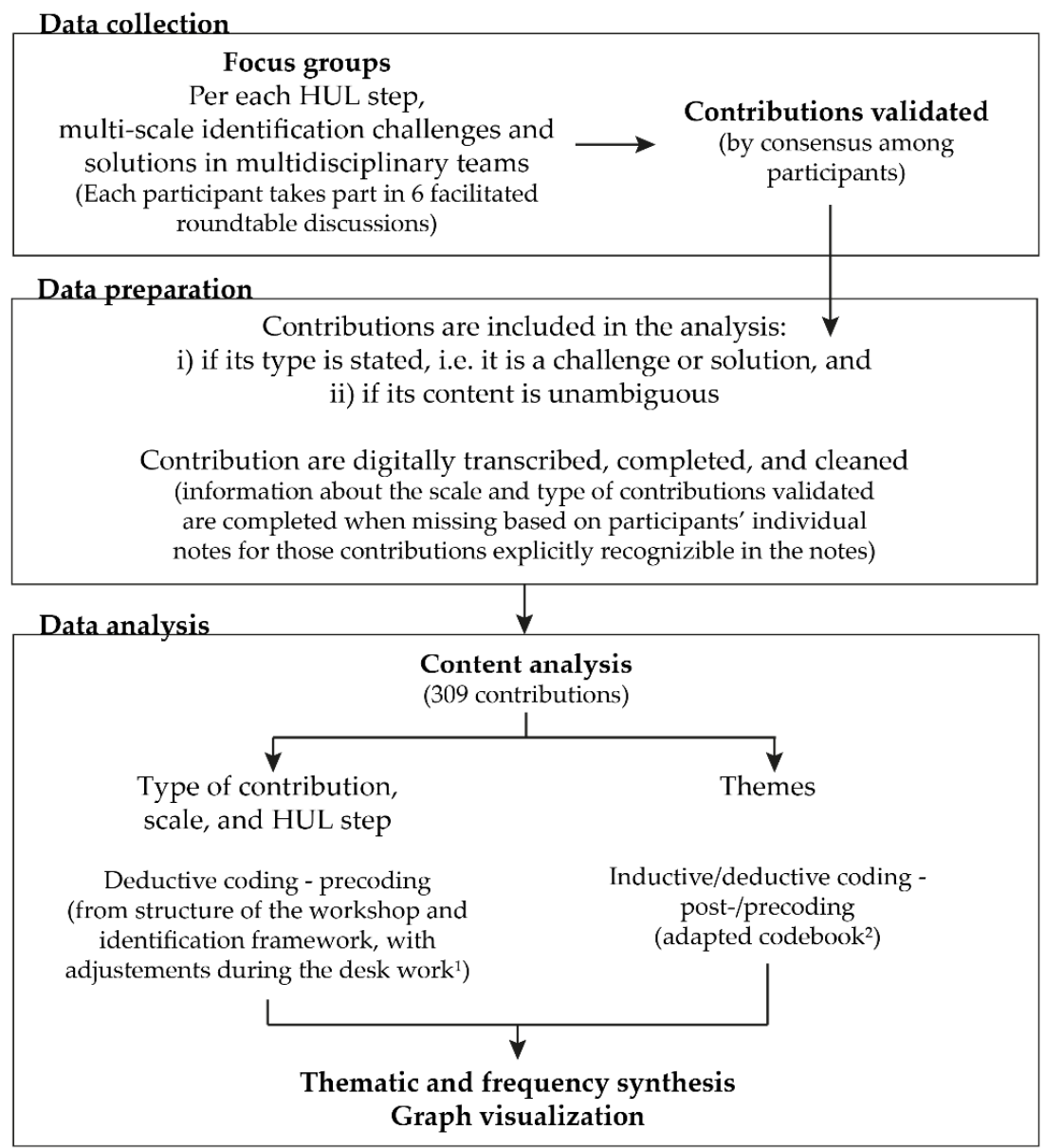

${ }^{1}$ During the analysis of the data collected the contributions associated with the scale code "elsewhere" were recoded as "general", to better reflect the use participants did of the code: providing contributions as general without specifying the referred context or scale. Furthermore, contributions for which the scale was not specified were assimilated to "general".

2 Pintossi et al. 2020

Figure 1. Overview of data collection and analysis processes.

\section{Results}

A comprehensive identification of challenges is key to facilitate the adaptive reuse of cultural heritage. This study identified such challenges based on primary data reflecting the participants' experience and opinions. The participants involved in the workshop also proposed solutions to tackle these challenges at multiple levels. The first part of this section presents an overview of the themes revealed by the content analysis. Afterward, the five most mentioned themes, i.e., those with higher frequencies, are discussed in further detail describing the challenges they refer to. These themes are participation, capacity, regulatory systems, economics-finance, and knowledge. Altogether, they represent a subset of $40 \%$ of the contributions analyzed.

The content analysis was performed on 309 contributions. Thematic synthesis of the coding resulted in the identification of 48 themes. These themes encompassed both challenges identified and solutions proposed (Figure 2). Besides offering an overview of the themes revealed by the analysis, the graph in Figure 2 illustrates their distribution by scale and contribution type. The themes associated with the most frequent codes concern participation and participatory practices $(n=33)$. This graph highlights that challenges referring to the same domain are encountered at different scales. 


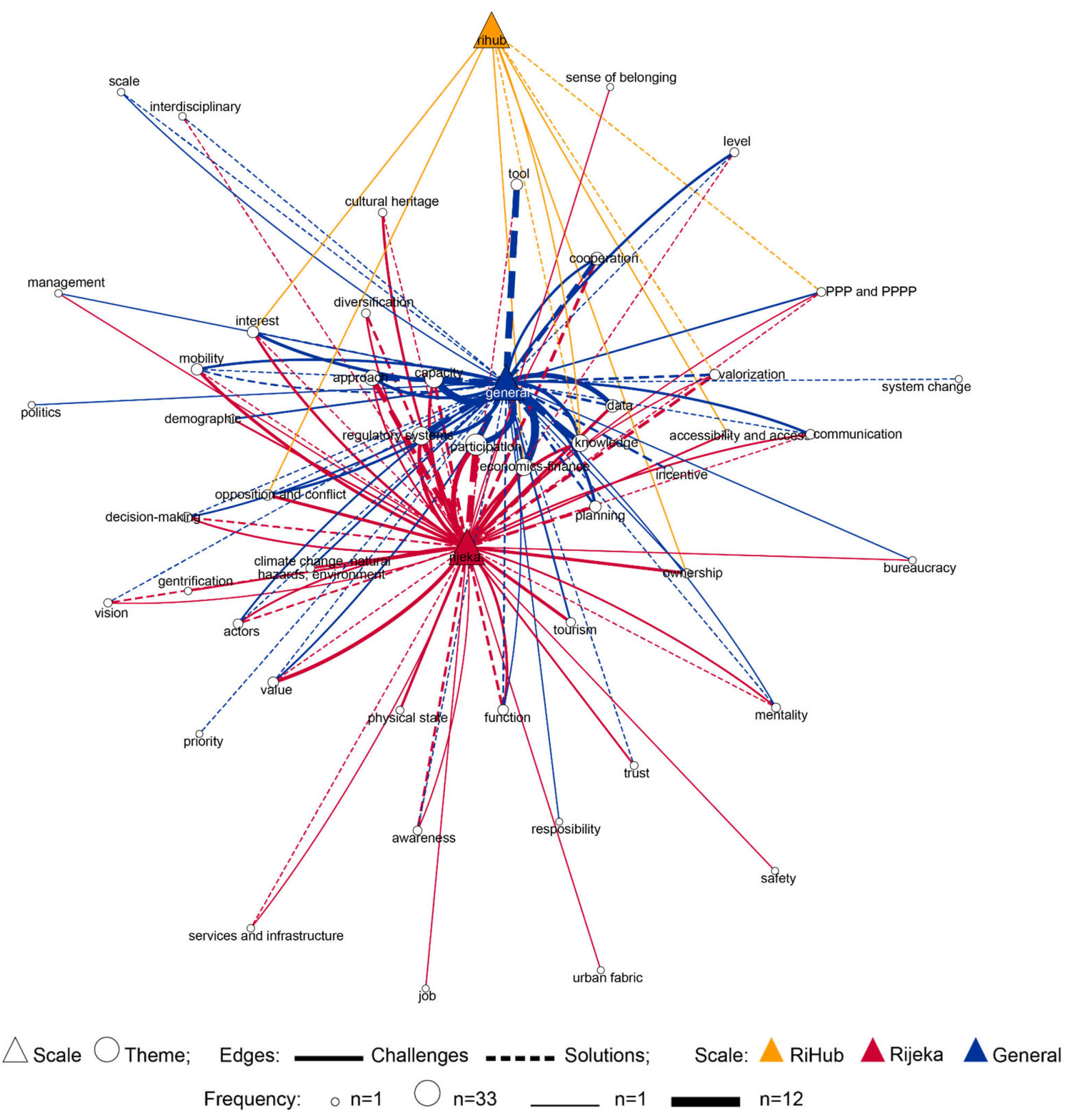

Figure 2. Overview of the challenges and solutions themes identified by content analysis. Themes are mapped using a two-mode, nonsimple, and multiedge graph with loops represented using a Prefuse Force-Directed layout with the number of contributions for each theme as the directing force. Graph created using Cytoscape 3.8.0 [113].

\subsection{Participation-Related Challenges}

In this study, participation challenges refer to the stakeholder engagement in the adaptive reuse of cultural heritage both at the urban level and as general issues. These challenges encompass the absence or limitation of participatory initiatives, and difficulties in implementing participation processes (Table 3). Some of the challenges were identified both at urban level and in general. 
Table 3. Participation-related challenges.

\begin{tabular}{|c|c|c|c|c|}
\hline Overarching Challenge & Challenges & Site Scale & Urban Scale & General \\
\hline \multirow[t]{2}{*}{$\begin{array}{c}\text { Absent or limited } \\
\text { participatory processes }\end{array}$} & Lack of participatory decision-making & & $\mathrm{x}$ & \\
\hline & $\begin{array}{l}\text { Lack of spontaneous participatory initiatives, } \\
\text { they are limited to the one organized by institutions }\end{array}$ & & & $\mathrm{x}$ \\
\hline \multirow[t]{6}{*}{$\begin{array}{l}\text { Implementation of } \\
\text { participatory practices }\end{array}$} & $\begin{array}{l}\text { Lack of or limited participation, low willingness } \\
\text { to participate }\end{array}$ & & $\mathrm{x}$ & $\mathrm{x}$ \\
\hline & $\begin{array}{l}\text { Lack of or limited representation of certain groups, } \\
\text { e.g., community, citizens }\end{array}$ & & $\mathrm{x}$ & $\mathrm{x}$ \\
\hline & $\begin{array}{c}\text { Stakeholders' perceived lack of qualification } \\
\text { to participate }\end{array}$ & & $\mathrm{x}$ & $x$ \\
\hline & Timing of participation & & $x$ & $\mathrm{x}$ \\
\hline & Stakeholder engagement & & $x$ & \\
\hline & Implement participation at various scales & & & $\mathrm{x}$ \\
\hline
\end{tabular}

In some cases, the challenge causes were also identified. For example, the low or complete lack of participation in Rijeka is due to the absence of a "culture of participation", the excessive bureaucracy, and trust issues toward institutions. Furthermore, engaging stakeholders is a challenge that derives from the stakeholders' perceived lack of qualification to take part in such processes, as well as from the low willingness to participate.

Based on these results, we noticed that challenges presented certain interdependencies. For example, the absence of participatory decision-making is due to the limited capacity available for bottom-up decision-making in Rijeka. Similarly, the lack of the willingness to participate also influences the lack of representation of certain groups while reinforcing the challenge of engaging stakeholders.

\subsection{Capacity-Related Challenges}

Challenges referring to capacity encompass the lack of capacity and limitations in the available capacity in terms of expertise, skills, and human resources for the adaptive reuse of cultural heritage both at the urban scale and in general (Table 4). In other words, a need for capacity building and limitations in available human resources and time available were identified. In addition, the absence of financial resources prevents the attraction of the needed expertise and tradesmen from other areas. This suggests that some financial- and capacity-related challenges are interdependent.

Table 4. Capacity-related challenges.

\begin{tabular}{|c|c|c|c|c|}
\hline Overarching Challenge & Challenges & Site Scale & Urban Scale & General \\
\hline \multirow[t]{3}{*}{ Lack of capacity } & $\begin{array}{l}\text { Absence of guidance for adaptive reuse of } \\
\text { cultural heritage }\end{array}$ & & $\mathrm{x}$ & $\mathrm{x}$ \\
\hline & Lack of local expertise and skilled tradesmen & & $x$ & $\mathrm{x}$ \\
\hline & $\begin{array}{l}\text { Loss of traditional skills and provision of youth } \\
\text { with skills }\end{array}$ & & & $\mathrm{x}$ \\
\hline $\begin{array}{l}\text { Limitation available } \\
\text { capacity }\end{array}$ & $\begin{array}{l}\text { Limited time available from available human } \\
\text { resources }\end{array}$ & & $\mathrm{x}$ & $\mathrm{x}$ \\
\hline & $\begin{array}{l}\text { Limited competence/specialization in the } \\
\text { public sector }\end{array}$ & & & $\mathrm{x}$ \\
\hline & Limited human resources & & & $x$ \\
\hline
\end{tabular}




\subsection{Regulatory-Related Challenges}

The adaptive reuse of cultural heritage also faces challenges that are linked to existing regulatory systems, encompassing regulations and policy documents (Table 5). In the city of Rijeka, some challenges specifically refer to the port area where several industrial heritage buildings and infrastructures, awaiting adaptive reuse, are located. Participants mentioned the difficulty of complying with the local regulations. For example, the use of the "same materials and craft skills" (contribution 107) is required in the adaptive reuse of the vessel Galeb-the formerly floating residence of the Yugoslav statesman Josip Broz Tito to be reused as a museum [114]. The results (Table 5) suggest the existence of a relation between the bylaw governing the procedure to apply for funding and some financial issues affecting the adaptive reuse of cultural heritage (\$3.5).

Table 5. Regulatory-related challenges.

\begin{tabular}{|c|c|c|c|c|}
\hline Overarching Challenge & Challenges & Site Scale & Urban Scale & General \\
\hline $\begin{array}{l}\text { Variety of strategy } \\
\text { documents }\end{array}$ & $\begin{array}{c}\text { Broad variety of strategy documents, need for } \\
\text { integration }\end{array}$ & & $\mathrm{x}$ & $\mathrm{x}$ \\
\hline \multirow[t]{3}{*}{$\begin{array}{l}\text { Compliance with } \\
\text { regulations }\end{array}$} & Land management plan for the port area & & $\mathrm{x}$ & \\
\hline & Requirements of local regulation for adaptive reuse & & $\mathrm{x}$ & \\
\hline & $\begin{array}{l}\text { Limitations/restrictions posed by the } \\
\text { planning regulation }\end{array}$ & & & $\mathrm{x}$ \\
\hline \multirow[t]{3}{*}{ Procedures } & Authorization of permits & & $\mathrm{x}$ & $\mathrm{x}$ \\
\hline & Strict regulation for concessions for the port area & & $x$ & \\
\hline & Regulation to access funding & & & $\mathrm{x}$ \\
\hline
\end{tabular}

\subsection{Economics-Finance-Related Challenges}

The economics-finance-related challenges encountered in the adaptive reuse of cultural heritage included the lack of funding to implement these interventions, as well as their financial sustainability over time, the perceived mismatch between the expenses and the results of some projects, and financial losses (Table 6). These issues are identified for all levels. At the site scale, the reliance of RiHub on the European Capital of Culture funding challenges its long-term viability after its termination. Similarly, concerns on the financial sustainability derive from the predominant reliance on European funding for other adaptive reuse projects and regeneration programs in Rijeka. The lack of financial resources is also a challenge for some heritage sites whose management was delegated by the national government to the local government without providing funding to support such a task. In addition, financial resources are also lacking to avert the decay of heritage that causes a financial loss because its worsening increases the costs of future interventions of restoration and repair. The lack of funding directly and indirectly hampers adaptive reuse. It indirectly affects processes, such as building capacity, creating additional challenges for heritage reuse (\$3.2). Besides showing the existence of influences among challenges, these results reveal the dynamic interlinkage among them. An example of this interlinkage is found among the lack of funding, the aggravation of the heritage decay, and the increase in intervention costs. 
Table 6. Economics-finance-related challenges.

\begin{tabular}{|c|c|c|c|c|}
\hline Overarching Challenge & Challenges & Site Scale & Urban Scale & General \\
\hline Financial loss & $\begin{array}{l}\text { Financial loss due to worsening of the decay } \\
\text { of heritage }\end{array}$ & & $x$ & $x^{1}$ \\
\hline \multirow[t]{2}{*}{ Financial sustainability } & Reliance on EU funding & $x$ & $x$ & \\
\hline & Lack of long-term revenue stream & $x$ & & \\
\hline \multirow[t]{5}{*}{$\begin{array}{l}\text { Lack of or limited } \\
\text { financial resources }\end{array}$} & $\begin{array}{l}\text { Lack of financial resources for coordination among } \\
\text { local authorities and among departments }\end{array}$ & & $\mathrm{x}$ & $\mathrm{x}$ \\
\hline & $\begin{array}{l}\text { Lack of financial resources for maintenance and } \\
\text { repair works, to implement adaptive reuse }\end{array}$ & & $\mathrm{x}$ & $x^{1}$ \\
\hline & $\begin{array}{c}\text { Lack of financial resources for specific activities (e.g., } \\
\text { mapping, keep information updated) }\end{array}$ & & & $\mathrm{x}$ \\
\hline & $\begin{array}{c}\text { Lack of financial resources for the adaptive reuse of } \\
\text { rural heritage }\end{array}$ & & & $\mathrm{x}$ \\
\hline & $\begin{array}{l}\text { Lack of financial resources to build capacity among } \\
\text { youth, to import experts, to attract professionals }\end{array}$ & & & $\mathrm{x}$ \\
\hline $\begin{array}{c}\text { Mismatch } \\
\text { investments-results }\end{array}$ & $\begin{array}{l}\text { Perceived high costs and expenses compared with } \\
\text { the results obtained }\end{array}$ & & $\mathrm{x}$ & \\
\hline
\end{tabular}

${ }^{1}$ This challenge refers to the national scale, i.e., the Republic of Croatia.

\subsection{Knowledge-Related Challenges}

The knowledge-related challenges refer to issues concerning what is known in relation to heritage and its adaptive reuse. These challenges, identified at the site and urban levels and as general ones, span from the lack of knowledge to its acquisition and loss (Table 7).

Table 7. Knowledge-related challenges.

\begin{tabular}{|c|c|c|c|c|}
\hline Overarching Challenge & Challenges & Site Scale & Urban Scale & General \\
\hline \multirow[t]{2}{*}{$\begin{array}{l}\text { Loss of knowledge and threat to } \\
\text { transmitting knowledge to } \\
\text { succeeding generations }\end{array}$} & $\begin{array}{l}\text { Loss of memory, stories, history, traditions, } \\
\text { and meaning of heritage }\end{array}$ & $\mathrm{x}$ & $\mathrm{x}$ & $\mathrm{x}$ \\
\hline & Threat to historic relation of the city with the sea & & $x$ & \\
\hline \multirow[t]{2}{*}{ Lack of knowledge } & $\begin{array}{c}\text { Lack of knowledge about the status of the } \\
\text { heritage resources }\end{array}$ & & & $\mathrm{x}$ \\
\hline & Lack of knowledge (without specification) & & & $\mathrm{x}$ \\
\hline Lack of integration & $\begin{array}{l}\text { The knowledge acquired by mapping lacks } \\
\text { integration within urban planning }\end{array}$ & & & $x$ \\
\hline
\end{tabular}

\section{Discussion}

Given the role of the adaptive reuse of cultural heritage as the entry point for circular cities and its contribution to cultural heritage conservation and sustainable urban development, the current study aimed to identify the challenges to the adaptive reuse of cultural heritage at multiple scales engaging a broad variety of stakeholders in a European case study, i.e., the port city of Rijeka. This challenge assessment can be regarded as a first step to facilitate the adaptive reuse of cultural heritage and thus harvests its potential for circular cities and sustainable development. The challenges were pinpointed by content analysis and frequency and the thematic synthesis of the data collected during a stakeholder engagement workshop. This workshop adopted the HUL approach and the World Café method. Participants in the study also suggested ways to overcome these hampering factors. In this section, these solutions are presented as recommendations (Figure 3). The analysis identified 48 themes (Figure 2) of challenges and solutions. Particularly, the five themes more 
frequently mentioned by participants were: Participation, capacity, regulatory systems, economics-finance, and knowledge.

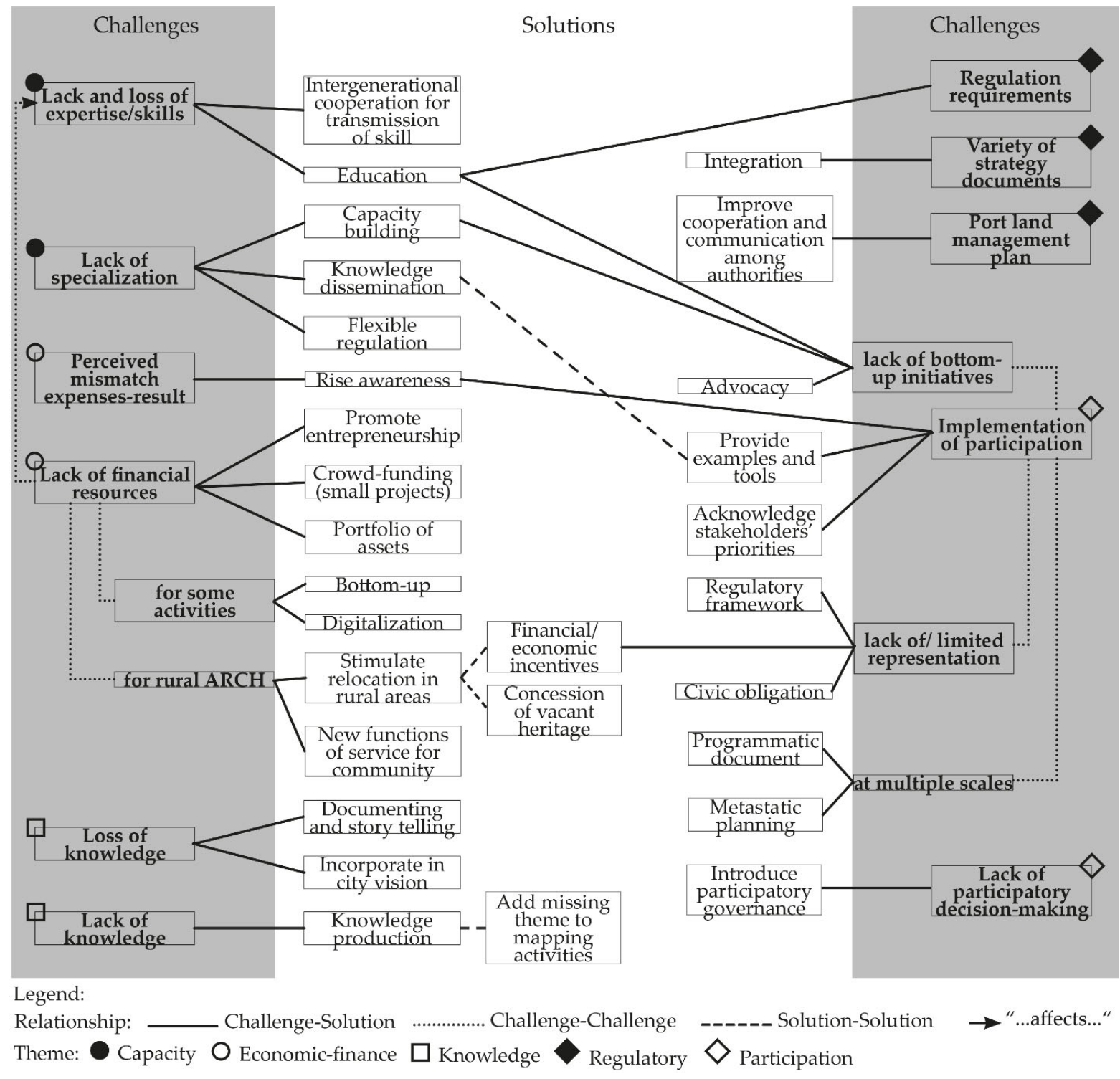

Figure 3. Concept map illustrating solutions to the five most mentioned challenges.

Notably, the novel challenges identified expand the range of factors hampering the adaptive reuse of cultural heritage beyond design concerns and compliance with codes and legal requirements. These novel challenges are:

- The absence or limitation of participatory processes,

- The implementation of participatory processes,

- The lack of guidance for the adaptive reuse of cultural heritage,

- The limitation of available capacity,

- The variety of strategy documents,

- The long-term economic sustainability (operational phase),

- The lack of financial resources for cooperation and capacity building,

- The loss of knowledge and traditional skills and the threat to transmitting them to succeeding generations,

- The lack of integration among sources of information,

- The depopulation. 
The literature mentions local communities in relation to challenges concerning conflicts about the new uses of the heritage, as well as ensuring the "continuity of local community life" [29] (p. 358). Yung and co-workers reported that community participation is absent in the decision-making without identifying it as a hindrance to reuse per se. Conversely, this study identified the absence or limitation of participatory processes as a challenge. In addition, the present findings indicate that challenges related to the implementation of participation (Table 3), such as the low willingness to participate and the limited representation of certain groups, are encountered beyond communities only. Yung et al., found that experts deemed the community participation problematic if its members lacked "an understanding of conservation, urban planning and cost analysis" [29] (p. 359). However, the present study suggests that the challenge to implement participation lays in the doubt of stakeholders about their own qualification in taking part in the adaptive reuse of cultural heritage processes. Concerning capacity-related challenges (Table 4), such as the lack of guidance for the adaptive reuse of cultural heritage, they add to the barrier posed by the availability of skilled tradesmen $[26,32,55]$. This availability issue was also identified by this study. In the literature, the economic viability as a challenge entails the conversion costs, the return on investment, and the lifecycle costs mentioning maintenance and running costs $[29,57,58]$, whereas less emphasis is placed on the long-term economic sustainability of the adaptive reuse of cultural heritage projects, such as the reliance on certain sources of funding or ensuring a long-term revenue stream (Table 6). Previous research highlighted that heritage reuse is hampered by the availability of reliable information [32]. The present findings also suggest that the lack of integration among sources of information challenges the adaptive reuse of cultural heritage processes (Table 7). Furthermore, this study pinpointed that the heritage reuse is challenged by the loss of knowledge and traditional skills, as well as the threat to their bestowal to future generations (Table 7). These issues relate to minimizing the change and preventing the loss of values that are barriers already identified in the literature $[29,57,63]$.

These findings support the hypothesis that engaging a broad variety of stakeholders of the adaptive reuse of cultural heritage is beneficial. We gathered a more extensive overview of the range of challenges encountered in these practices but only reported in detail the five most mentioned ones as part of this study. In addition, the numerous challenges identified at the urban scale provide evidence that the adaptive reuse of cultural heritage is hampered not only by site-specific challenges.

In addition, this study also identified challenges that had already been reported in the literature (Table 1). This suggests the transferability of the results presented in literature considering case studies in East Asia, Oceania, and North America (e.g., [29,32,56,115]) to the port city of Rijeka. It is confirmed that design-oriented challenges, e.g., compliance with regulations and codes, also apply to this case study. Yet, the challenges identified by the participants subsume characteristics that are context-specific [116]. For example, in Rijeka, the challenges are associated with the compliance with the land management plan for the port area instead of the zoning in general [32].

Among the challenges that had already been identified in the literature, it is worth mentioning the one posed by the stigma associated with the site also reported by Wilkinson [70]. This challenge refers to the intangible dimension of the heritage to reuse. Particularly, in Rijeka, some stakeholders contest the adaptive reuse of Galeb_former floating residence of the Yugoslav statesman Josip Broz Tito. The reason for the contestation is that the "difficult history is still alive". On the one hand, this challenge exemplifies that cultural heritage is not devoid of conflicts, contestation, and contradiction [17,21]. On the other hand, it suggests the importance of the intangible dimension of heritage in its adaptive reuse.

Notably, this research also presents evidence of the interdependence, as well as the dynamic mutual interaction existing among some challenges, such as the lack of the willingness to participate influencing the lack of representation of certain groups. In some cases, participants also identified the causes of some challenges, e.g., lacking participation was due to trust issues. Based on these results, it is also suggested that for the adaptive reuse 
of cultural heritage, the understanding of challenges needs to be performed with a systemic approach instead of in isolation. This is in accordance with the recommendation of prior studies on barriers to climate change adaptation [116], implementation of nature-based solutions [79], and heritage climate change adaptation [117]. To the best of our knowledge, this is one of the first studies reporting evidence on causes and interdependences among challenges to the adaptive reuse of cultural heritage. This study, based on manifest content analysis, limited the identification of interdependences to those explicitly presented in the data. Nevertheless, the literature on barriers in other domains suggests the existence of a broader network of interdependences. For example, it is found that funding barriers drive institutional barriers in heritage climate change adaptation [117]. Likely, it can be inferred that the limited availability of human resources for the adaptive reuse of cultural heritage identified in this study is due to a lack of financial resources. Therefore, the findings on the relationships among challenges are preliminary insights that raise questions about what other relationships exist and which ones prevail.

Based on the above findings, a reference framework to address the challenges identified is outlined in the form of a concept map (Figure 3). The solutions reported in this map are derived from participants. First, some solutions are common to more challenges. For example, on the one hand, activities raising awareness of the benefits of heritage reuse can help overcome the perceived mismatch between the expenses incurred for it and the results obtained. On the other hand, raising awareness of the benefits of participation in heritage reuse can facilitate its implementation. Second, a solution while directly tackling a specific challenge could also indirectly address challenges that are interlinked to the one directly tackled. Namely, resolving the lack of financial resources could also favor addressing the loss of expertise and skills. This suggests that synergies could be exploited in overcoming challenges. Hence, both challenges and solutions could benefit from a systemic approach combining actions and strategies, instead of addressing the challenges one by one.

This study illustrates the variety of challenges faced by the adaptive reuse of cultural heritage, identifying novel challenges and proposing solutions to overcome them. This overview informs policymakers, decision-makers, and stakeholders engaged in the adaptive reuse of cultural heritage processes. Raising awareness of the current challenges and their scale of application can help address them, thus facilitating the implementation of the adaptive reuse of cultural heritage. Outlining some of the interdependences existing among challenges offers insights into their co-occurrence. This suggests the need to address these issues in a systemic way, also considering the nonmutual exclusivity of some challenges. The insights into challenges coupled with the reference framework provide knowledge to develop actions, strategies, and policies to facilitate the adaptive reuse of cultural heritage practices. Besides informing these practices, the overview can also be of relevance to practitioners in the fields of heritage management and conservation, as well as urban planning and development.

Furthermore, the results presented can contribute to the expanding literature on the sustainable development and regeneration of port cities and areas [118-120] by presenting the adaptive reuse of cultural heritage within the port city of Rijeka. In fact, port areas are recognized as having a potential role in sustainable development starting with their heritage $[59,62,121]$. Yet, limitations are present to the applicability of these results as they are based on a case study.

Although this study offers an overview of the challenges to the adaptive reuse of cultural heritage in the port city of Rijeka, providing insights to the future adaptive reuse of cultural heritage practices and policymaking to facilitate them, it also presents some limitations. First, the transferability of the findings to other contexts was not tested. Second, the exploratory characteristics of this study rely on the participants' experiences. Particularly, as the findings are based on participants' consensus, contradictions among different actors might not be captured. In other words, a category of actors might consider a factor as a barrier, whereas another determines it as an opportunity [26,116]. Finally, 
only a few contributions considered the site scale, whereas the majority focused on the urban scale or general factors. On the one hand, this might introduce a scale bias; hence, results were not discussed from this perspective. On the other hand, the extent of the generalizability of the general factors is to be further validated.

\section{Conclusions}

As a strategy for heritage conservation, sustainable development, and the entry point for circular cities, the adaptive reuse of cultural heritage is receiving increasing attention. However, the implementation of these heritage reuse processes is hampered by several challenges. This paper aimed to identify the challenges to the adaptive reuse of cultural heritage by engaging a broad range of stakeholders, as well as considering a multi-scale perspective.

Based on our research, stakeholders identified a variety of novel challenges for the adaptive reuse of cultural heritage both at the urban and site level, such as the implementation of participatory practices, the absence of guidance for the adaptive reuse of cultural heritage, and the economic-financial sustainability in the operational phase of reused heritage. This research not only introduces novel challenges to the adaptive reuse of cultural heritage, but it also proves the transferability of some of the issues reported in the literature to the city of Rijeka. In addition, these findings highlight that the use of a multiscale perspective and of a landscape-based approach provides more insights into the variety of challenges hindering heritage reuse practices. Solutions were also proposed based on the stakeholders' suggestions, and interdependences among challenges were revealed.

The results of this research suggest the need for a systemic approach coupled with a multi-scale perspective in addressing the challenges to the adaptive reuse of cultural heritage. The overview of these challenges and the proposed solutions raise awareness among the stakeholders involved in implementing heritage reuse, as well as provide evidence to policymakers and decision-makers. This is the first step to finding synergic strategies to address the challenges to the adaptive reuse of cultural heritage. Addressing these issues can facilitate these conservation practices that are key to circular cities and play a role in sustainable urban development.

Future research is needed to identify the relationship existing among challenges in order to identify those that are preconditions to tackle other challenges. Similarly, additional research is required concerning the solutions and their implementation to address the system of challenges outlined in the present study. Furthermore, as the challenges are context, time, and actor-specific, and as this study is based on a case study, future research can investigate the application of the present findings in other contexts.

Author Contributions: Conceptualization N.P. and A.P.R.; methodology, all authors; validation, D.I.K.; formal analysis, N.P.; investigation, N.P.; resources, N.P. and A.P.R.; data curation, N.P.; writing—original draft preparation, N.P.; writing—review and editing, all authors; visualization, N.P.; supervision, A.P.R. and D.I.K.; project administration, N.P. and D.I.K.; funding acquisition, A.P.R. We thank the anonymous reviewers for their insightful comments and suggestions. All authors have read and agreed to the published version of the manuscript.

Funding: This research was funded by the European Union's Horizon 2020 research and innovation programme, grant number 776758 .

Institutional Review Board Statement: Not applicable.

Informed Consent Statement: Informed consent was obtained from all subjects involved in the study.

Data Availability Statement: The archived datasets analyzed are deposited at 10.5281/zenodo.4518743.

Acknowledgments: We thank the participants of the workshop and the CLIC partners for their contributions. We acknowledge the cooperation of Marco Acri, Martina Bosone, Silvia Iodice, and Lu Lu who joined N.P. and D.I.K. in facilitating the sessions of roundtable discussion. We also thank Marco Acri, Suzanna Belosevic, Mirta Klaričić, and Dunja Zagorac for the support in organizing the workshop. 
Conflicts of Interest: The authors declare no conflict of interest. The funders had no role in the design of the study; in the collection, analyses, or interpretation of data; in the writing of the manuscript, or in the decision to publish the results.

\section{References}

1. United Nations (Habitat III) The New Urban Agenda. Available online: http://habitat3.org/wp-content/uploads/NUA-English pdf (accessed on 9 December 2019).

2. UNDESA World Urbanization Prospects: The 2018 Revision. Key Facts. Available online: https://esa.un.org/unpd/wup/ Publications/Files/WUP2018-KeyFacts.pdf (accessed on 30 July 2018).

3. Report of the World Commission on Environment and Development: Our Common Future. Available online: http://www.undocuments.net/our-common-future.pdf (accessed on 17 November 2017).

4. Ellen MacArthur Foundation Completing the Picture: How the Circular Economy Tackles Climate Change. Available online: https://www.ellenmacarthurfoundation.org/assets/downloads/Completing_The_Picture_How_The_Circular_Economy_Tackles_Climate_Change_V3_26_September.pdf (accessed on 9 December 2019).

5. European Commission Communication from the Commission to the European Parliament, the Council, the European Economic and Social Committee and the Committee of the Regions. Closing the Loop-An EU Action Plan for the Circular Economy. COM(2015) 614 Final. Available online: https://eur-lex.europa.eu/legal-content/EN/TXT/?uri=CELEX\%3A52015DC0614 (accessed on 3 November 2020).

6. Foster, G.; Kreinin, H. A review of environmental impact indicators of cultural heritage buildings: A circular economy perspective. Environ. Res. Lett. 2020, 15, 043003. [CrossRef]

7. Kirchherr, J.; Reike, D.; Hekkert, M. Conceptualizing the circular economy: An analysis of 114 definitions. Resour. Conserv. Recycl. 2017, 127, 221-232. [CrossRef]

8. UN Environment and International Energy Agency Towards a Zero-Emission, Efficient, and Resilient Buildings and Construction Sector. Global Status Report 2017. Available online: https:/ /www.worldgbc.org/sites/default/files/UNEP188_GABC_en\%28 web\%29.pdf (accessed on 10 March 2021).

9. Davos Declaration 2018. Available online: https://davosdeclaration2018.ch/media/Brochure_Declaration-de-Davos-2018_WEB_ 2.pdf (accessed on 13 February 2020).

10. Guzmán, P.C.; Pereira Roders, A.R.; Colenbrander, B.J.F. Measuring links between cultural heritage management and sustainable urban development: An overview of global monitoring tools. Cities 2017, 60, 192-201. [CrossRef]

11. UNESCO The Hangzhou Declaration: Placing Culture at the Heart of Sustainable Development Policies. Available online: http:/ / www.unesco.org/new/fileadmin/MULTIMEDIA/HQ/CLT/images/FinalHangzhouDeclaration20130517.pdf (accessed on 21 January 2021).

12. Berg, S.K. Cultural heritage as a resource for property development. Hist. Environ. Policy Pract. 2017, 8, 304-322. [CrossRef]

13. United Nations General Assembly Transforming Our World: The 2030 Agenda for Sustainable Development. Available online: https:/ / sustainabledevelopment.un.org/content/documents/21252030\%20Agenda\%20for\%20Sustainable\%20Development $\%$ 20web.pdf (accessed on 21 January 2020).

14. Council of Europe Council of Europe Framework Convention on the Value of Cultural Heritage for Society. Available online: https: / rm.coe.int/1680083746 (accessed on 21 January 2021).

15. Akagawa, N. Authorized Heritage Discourse. In The Encyclopedia of Archaeological Sciences; John Wiley \& Sons, Inc.: Hoboken, NJ, USA, 2018; pp. 1-4.

16. Bandarin, F. Reshaping Urban Conservation. In Reshaping Urban Conservation. The Historic Urban Landscape Approach in Action; Pereira Roders, A., Bandarin, F., Eds.; Springer: Singapore, 2019; pp. 3-20.

17. Smith, L. Discourses of heritage: Implications for archaeological community practice. Nuevo Mundo Mundos Nuevos 2012. [CrossRef]

18. Tweed, C.; Sutherland, M. Built cultural heritage and sustainable urban development. Landsc. Urban Plan. 2007, 83, 62-69. [CrossRef]

19. Vecco, M. A definition of cultural heritage: From the tangible to the intangible. J. Cult. Herit. 2010, 11, 321-324. [CrossRef]

20. van Oers, R. Cultural Heritage Management and Sustainability. In Perceptions of Sustainability in Heritage Studies; Albert, M.-T., Ed.; De Gruyter: Berlin, Germany, 2015; pp. 189-202.

21. Pereira Roders, A. The Historic Urban Landscape approach in action: Eight years later. In Reshaping Urban Conservation. The Historic Urban Landscape Approach in Action; Pereira Roders, A., Bandarin, F., Eds.; Springer: Singapore, 2019 ; pp. 21-54. ISBN 978-981-10-8886-5.

22. UNESCO Recommendation on the Historic Urban Landscape. Available online: https://whc.unesco.org/en/hul/ (accessed on 26 June 2018).

23. Landorf, C. Social sustainability and urban heritage: The challenge of conserving physical places and sustaining cultural traces. In Urban Social Sustainability: Theory, Policy and Practice; Shirazi, M.R., Keivani, R., Eds.; Routledge: London, UK, 2019; pp. 78-98. ISBN 9781351631532. Available online: https:/ /www-taylorfrancis-com.dianus.libr.tue.nl/chapters/social-sustainability-urbanheritage-chris-landorf/e/10.4324/9781315115740-5? context=ubx\&refId=7df76864-df99-4903-865c-62bdeef7faa8 (accessed on 5 March 2021). 
24. Australia ICOMOS. The Burra Charter: The Australia ICOMOS Charter for Places of Cultural Significance. Available online: http: / / australia.icomos.org/ (accessed on 4 September 2020).

25. ICOMOS. The Nara Document on Authenticity. Available online: https://www.icomos.org/charters/nara-e.pdf (accessed on 7 September 2020).

26. Bullen, P.A.; Love, P.E.D. Adaptive reuse of heritage buildings. Struct. Surv. 2011, 29, 411-421. [CrossRef]

27. CHCfE Consortium Cultural Heritage Counts for Europe. Available online: www.encatc.org/culturalheritagecountsforeurope (accessed on 5 September 2018).

28. Council of Europe Council conclusions of 21 May 2014 on Cultural Heritage as a Strategic Resource for a Sustainable Europe. Available online: https: / / eur-lex.europa.eu/legal-content/EN/TXT/PDF/?uri=CELEX:52014XG0614(08)\&from=EN (accessed on 10 March 2021).

29. Yung, E.H.K.; Chan, E.H.W. Implementation challenges to the adaptive reuse of heritage buildings: Towards the goals of sustainable, low carbon cities. Habitat Int. 2012, 36, 352-361. [CrossRef]

30. Landorf, C. A Framework for Sustainable Heritage Management: A Study of UK Industrial Heritage Sites. Int. J. Herit. Stud. 2009, 15, 494-510. [CrossRef]

31. Fusco Girard, L. Implementing the circular economy: The role of cultural heritage as the entry point. Which evaluation approaches? BDC-Bollettion del Cent. Calza Bini 2019, 9, 245-277. [CrossRef]

32. Conejos, S.; Langston, C.; Chan, E.H.W.W.; Chew, M.Y.L.L. Governance of heritage buildings: Australian regulatory barriers to adaptive reuse. Build. Res. Inf. 2016, 3218, 507-519. [CrossRef]

33. Douglas, J. Building Adaptation, 2nd ed.; Butterworth-Heinemann: Oxford, UK, 2006; ISBN 9780750666671.

34. Foster, G. Circular economy strategies for adaptive reuse of cultural heritage buildings to reduce environmental impacts. Resour. Conserv. Recycl. 2020, 152, 104507. [CrossRef]

35. Homrich, A.S.; Galvão, G.; Abadia, L.G.; Carvalho, M.M. The circular economy umbrella: Trends and gaps on integrating pathways. J. Clean. Prod. 2018, 175, 525-543. [CrossRef]

36. Ellen MacArthur Foundation Intelligent Assets: Unlocking the Circular Economy Potential. Available online: http://www. ellenmacarthurfoundation.org/assets/downloads / publications/EllenMacArthurFoundation_Intelligent_Assets_080216.pdf (accessed on 17 July 2018).

37. Fusco Girard, L. The circular economy in transforming a died heritage site into a living ecosystem, to be managed as a complex adaptive organism. Aestimum 2020. [CrossRef]

38. Bosone, M.; Micheletti, S.; Gravagnuolo, A.; Garzillo, C.; Wildman, A. Towards a ciruclar governance for the adaptive reuse of cultural heritage. BDC-Boll. del Cent. Calza Bini 2019, 19, 279-305.

39. Ruba, S.; Drouillon, P.; Ost, C. D4.5 Circular Business Model Workshops for Cultural Heritage Adaptive Reuse. Available online: https:/ / www.clicproject.eu/files/D4-5.pdf (accessed on 5 February 2021).

40. Rodwell, D. Conservation and Sustainability in Historic Cities; Blackwell Publishing Ltd.: Hoboken, NJ, USA, 2007; ISBN 978-1-40512656-4.

41. Conejos, S.; Yung, E.H.K.; Chan, E.H.W. Evaluation of urban sustainability and adaptive reuse of built heritage areas: A case study on conservation in Hong Kong's CBD. J. Des. Res. 2014, 12, 260-279. [CrossRef]

42. Mohamed, R.; Boyle, R.; Yang, A.Y.; Tangari, J. Adaptive reuse: A review and analysis of its relationship to the 3 Es of sustainability. Facilities 2017, 35, 138-154. [CrossRef]

43. Bullen, P.A.; Love, P.E.D. The rhetoric of adaptive reuse or reality of demolition: Views from the field. Cities 2010, 27, 215-224 [CrossRef]

44. Architects' Council of Europe Leeuwarden Declaration: Adaptive Re-Use of the Built Heritage: Preserving and Enhancing the Values of Our Built Heritage for Future Generations. Available online: https:/ / www.ace-cae.eu/uploads/tx_jidocumentsview / LEEUWARDEN_STATEMENT_FINAL_EN-NEW.pdf (accessed on 13 February 2020).

45. Giuliani, F.; De Falco, A.; Landi, S.; Bevilacqua, M.G.; Santini, L.; Pecori, S.; De Falco, A.; Landi, S.; Giorgio Bevilacqua, M.; Santini, L.; et al. Reusing grain silos from the 1930s in Italy. A multi-criteria decision analysis for the case of Arezzo. J. Cult. Herit. 2018, 29, 145-159. [CrossRef]

46. Yung, E.H.K.; Chan, E.H.W.; Xu, Y. Community-Initiated Adaptive Reuse of Historic Buildings and Sustainable Development in the Inner City of Shanghai. J. Urban Plan. Dev. 2014, 140, 05014003. [CrossRef]

47. Elrod, J.K.; Fortenberry, J.L. Advancing indigent healthcare services through adaptive reuse: Repurposing abandoned buildings as medical clinics for disadvantaged populations. BMC Health Serv. Res. 2017, 17, 805. [CrossRef]

48. Plevoets, B.; Van Cleempoel, K. Adaptive Reuse of the Built Heritage; Routledge: Abingdon, UK, 2019.

49. Chen, C.-S.C.-S.; Chiu, Y.-H.Y.-H.; Tsai, L. Evaluating the adaptive reuse of historic buildings through multicriteria decisionmaking. Habitat Int. 2018, 81, 12-23. [CrossRef]

50. Fatorić, S.; Egberts, L. Realising the potential of cultural heritage to achieve climate change actions in the Netherlands. J. Environ. Manag. 2020, 274, 111107. [CrossRef]

51. Foster, G.; Saleh, R. The Adaptive Reuse of Cultural Heritage in European Circular City Plans: A Systematic Review. Sustainability 2021, 13, 2889. [CrossRef]

52. Tam, V.W.Y.; Hao, J.J.L. Adaptive reuse in sustainable development. Int. J. Constr. Manag. 2019, 19, 509-521. [CrossRef] 
53. Olivadese, R.; Remøy, H.; Berizzi, C.; Hobma, F. Reuse into housing: Italian and Dutch regulatory effects. Prop. Manag. 2017, 35, 165-180. [CrossRef]

54. Bullen, P.A.; Love, P.E.D. Factors influencing the adaptive re-use of buildings. J. Eng. Des. Technol. 2011, 9, 32-46. [CrossRef]

55. Aigwi, I.E.; Egbelakin, T.; Ingham, J. Efficacy of adaptive reuse for the redevelopment of underutilised historical buildings: Towards the regeneration of New Zealand's provincial town centres. Int. J. Build. Pathol. Adapt. 2018, 36, 385-407. [CrossRef]

56. Elrod, J.K.; Fortenberry, J.L. Adaptive reuse in the healthcare industry: Repurposing abandoned buildings to serve medical missions. BMC Health Serv. Res. 2017, 17, 5-14. [CrossRef]

57. Shipley, R.; Utz, S.; Parsons, M. Does adaptive reuse pay? A study of the business of building renovation in Ontario, Canada. Int. J. Herit. Stud. 2006, 12, 505-520. [CrossRef]

58. Tan, Y.; Shuai, C.; Wang, T. Critical success factors (CSFs) for the adaptive reuse of industrial buildings in Hong Kong. Int. J. Environ. Res. Public Health 2018, 15, 1546. [CrossRef] [PubMed]

59. Fernandes, A.; Figueira de Sousa, J.; Costa, J.P.; Neves, B. Mapping stakeholder perception on the challenges of brownfield sites ${ }^{\prime}$ redevelopment in waterfronts: The Tagus Estuary. Eur. Plan. Stud. 2020, 1-18. [CrossRef]

60. Vrusho, B.; Pashako, F. Adaptive Reuse of Underused Industrial Sites, Case Study: The Superphosphate of Lac. In Proceedings of the Putting Tradition into Practice: Heritage, Place and Design; Amoruso, G., Ed.; Springer International Publishing AG: Cham, Switzerland, 2018; Volume 3, pp. 1097-1112.

61. Clark, J. Adaptive Reuse of Industrial Heritage: Opportunities \& Challenges; Heritage Council of Victoria: Melbourne, Australia, 2013.

62. Hettema, J.; Egberts, L. Designing with maritime heritage: Adaptive re-use of small-scale shipyards in northwest Europe. J. Cult. Herit. Manag. Sustain. Dev. 2019, 10, 130-143. [CrossRef]

63. Mehr, S.Y.; Skates, H.; Holden, G. Adding more by using Less: Adaptive reuse of woolstores. In Proceedings of the Procedia Engineering; Elsevier: Sydney, Australia, 2017; Volume 180, pp. 697-703.

64. Wilkinson, S.J.; Remøy, H.; Langston, C. Designing for Future Adaptive Reuse. In Sustainable Building Adaptation; Wiley Blackwell: Hoboken, NJ, USA, 2014; pp. 250-272.

65. Langston, C.; Shen, L.Y. Application of the adaptive reuse potential model in Hong Kong: A case study of Lui Seng Chun. Int. J. Strateg. Prop. Manag. 2007, 11, 193-207. [CrossRef]

66. Bourne, L.S. Reurbanization, Uneven Urban Development, and the Debate on New Urban Forms. Urban Geogr. 1996, 17, 690-713. [CrossRef]

67. Steinberg, F. Conservation and rehabilitation of urban heritage in developing countries. Habitat Int. 1996, 20, 463-475. [CrossRef]

68. Remøy, H.; Van Der Voordt, T. Adaptive reuse of office buildings into housing: Opportunities and risks. Build. Res. Inf. 2014, 42, 381-390. [CrossRef]

69. Dyson, K.; Matthews, J.; Love, P.E.D. Critical success factors of adapting heritage buildings: An exploratory study. Built Environ. Proj. Asset Manag. 2016, 6, 44-57. [CrossRef]

70. Wilkinson, S.J. Drivers and Barriers for Adaptation. In Sustainable Building Adaptation: Innovations in Decision-Making; Wilkinson, S.J., Remøy, H., Langston, C., Eds.; Wiley-Blackwell: Hoboken, NJ, USA, 2014; pp. 18-41.

71. Yildirim, M. Assessment of the decision-making process for re-use of a historical asset: The example of Diyarbakir Hasan Pasha Khan, Turkey. J. Cult. Herit. 2012, 13, 379-388. [CrossRef]

72. Wilkinson, S.J. The Context for Building Resilience through Sustainable Change of Use Adaptation. In Building Urban Resilience through Change of Use; Wilkinson, S.J., Remøy, H., Eds.; Wiley Blackwell: Hoboken, NJ, USA, 2018; pp. 1-20.

73. Galdini, R. Urban re-use practices in contemporary cities: Experiences in Europe. Cities 2019, 87, 103-105. [CrossRef]

74. Ginzarly, M.; Houbart, C.; Teller, J. The Historic Urban Landscape approach to urban management: A systematic review. Int. J. Herit. Stud. 2019, 25, 999-1019. [CrossRef]

75. Gray, B. Collaboration: Finding Common Ground for Multi-Party Problems; Josey-Bass Publishers: San Francisco, CA, USA, 1989.

76. Landorf, C. Managing for sustainable tourism: A review of six cultural World Heritage Sites. J. Sustain. Tour. 2009, 17, 53-70. [CrossRef]

77. Arnstein, S.R. A Ladder of Citizen Participation. J. Am. Inst. Plann. 1969, 35, 216-224. [CrossRef]

78. Patton, M.Q. Qualitative Research E Evaluation Methods: Integrating Theory and Practice; SAGE Publications Inc.: Thousand Oaks, CA, USA, 2015.

79. Sarabi, S.; Han, Q.; Romme, A.G.L.; de Vries, B.; Valkenburg, R.; den Ouden, E. Uptake and implementation of Nature-Based Solutions: An analysis of barriers using Interpretive Structural Modeling. J. Environ. Manag. 2020, 270, 110749. [CrossRef] [PubMed]

80. Misırlısoy, D.; Günce, K. Adaptive reuse strategies for heritage buildings: A holistic approach. Sustain. Cities Soc. 2016, 26, 91-98. [CrossRef]

81. Wilkinson, S.J. Defining Adaptation. In Sustainable Building Adaptation: Innovations in Decision-Making; Wilkinson, S.J., Remøy, H., Langston, C., Eds.; Wiley Blackwell: Hoboken, NJ, USA, 2014; pp. 3-17. ISBN 9781118477106.

82. Reshaping Urban Conservation. The Historic Urban Landscape Approach in Action, 1st ed.; Pereira Roders, A., Bandarin, F., Eds.; Springer: Singapore, 2019; pp. 91-109. ISBN 978-981-10-8886-5.

83. Van Oers, R. Swahili Historic Urban Landscapes: Report on the Historic Urban Landscape Workshops and Field Activities on the Swahili coast in East Africa 2011-2012; UNESCO: Paris, France, 2013. 
84. Gravagnuolo, A.; Girard, L.F. Multicriteria tools for the implementation of historic urban landscape. Qual. Innov. Prosper. 2017, 21, 186-201. [CrossRef]

85. WHITRAP. City of Ballarat The HUL Guidebook: Managing Heritage in Dynamic and Constantly Changing Urban Environments. A Practical Guide to UNESCO's Recommendtion on the Historic Urban Landscape. Available online: http: //historicurbanlandscape.com/themes/196/userfiles/download/2016/6/7/wirey5prpznidqx.pdf (accessed on 18 March 2019).

86. Veldpaus, L. Historic Urban Landscapes: Framing the Integration of Urban and Heritage Planning in Multilevel Governance. Ph.D. Thesis, Technische Universiteit Eindhoven, Eindhoven, The Netherlands, 2015.

87. Ikiz Kaya, D.; Pintossi, N.; Dane, G. An Empirical Analysis of Driving Factors and Policy Enablers of Heritage Adaptive Reuse within the Circular Economy Framework. Sustainability 2021, 13, 2479. [CrossRef]

88. Pintossi, N.; Ikiz Kaya, D.; Pereira Roders, A. Adaptive Reuse of Cultural Heritage in Amsterdam: Identifying challenges and solutions through the Historic Urban Landscape approach. In Proceedings of the LDE Heritage Conference on Heritage and the Sustainable Development Goals: Proceedings; Pottgiesser, U., Fatorić, S., Hein, C., de Maaker, E., Pereira Roders, A., Eds.; TU Delft Open: Delft, The Netherlands, 2021; pp. 304-314.

89. Rijeka 2020 Buildings Renovation: RiHub. Available online: https:/ /rijeka2020.eu/en/about-the-project/buildings-renovation/ rihub/ (accessed on 21 January 2021).

90. Grad Rijeka RiHub. Available online: https://www.rijeka.hr/gradska-uprava/gradski-projekti/realizirani-projekti/rihub/ (accessed on 21 January 2021).

91. Rijeka 2020 About Us: Meeting Place. Available online: https:/ / dyxvzweoxwd33kn2xityw2ohfa--rijeka2020-eu.translate.goog/ projekti/rihub/o-nama/ (accessed on 21 January 2021).

92. Rijeka 2020 RiHub Vying for the Bernardo Bernardi Award. Available online: https:/ / rijeka2020.eu/en/rihub-vying-for-thebernardo-bernardi-award/ (accessed on 21 January 2020).

93. Pintossi, N.; Ikiz Kaya, D. Deliverable D1.1: Report of the HUL Workshops; Eindhoven University of Technology: Eindhoven, The Netherlands, 2020.

94. Arhitektura Secesije u Rijeci. Available online: https://hr.wikipedia.org/wiki/Arhitektura_secesije_u_Rijeci (accessed on 21 January 2020).

95. Rijeka Heritage Kindergarten of the Sisters of Mercy. Available online: https://rijekaheritage.org/en/kj/djecjivrticsestaramilosrdnica (accessed on 21 January 2021).

96. Rameša, R. RiHub. L'iniziativa che guarda al futuro [RiHub. The Initiative Looking towards the Future]. Available online: http: / / editfiume.info/editnews/cronaca/cronaca-fiumana/3811-rihub-1-iniziativa-che-guarda-al-futuro (accessed on 21 January 2021).

97. Grad Rijeka Nagrada „Bernardo Bernardi“ Ani Boljar i Idi Križaj Leko za unutarnje uređenje prostora RiHub [Bernardo Bernardi Award to Ana Boljar and Idi Križaj Leko for RiHub Interior Design]. Available online: https://www.rijeka.hr/nagrada-bernardobernardi-ani-boljar-idi-krizaj-leko-za-unutarnje-uredenje-prostora-rihub / (accessed on 21 January 2021).

98. Lozzi-Barkoviae, J. Industrial Heritage in the Culture Tourism of the City of Rijeka. In Proceedings of the TICCIH International Congress 2006, The International Committee for the Conservation of the Industrial Heritage, Terni, Italy, 14-18 September 2006.

99. Lovra, E. Urban Tissue Typology and Urban Typology (1868-1918). Prostor 2016, 24, 202-215. [CrossRef]

100. Ažman Momirski, L. The Resilience of the Port Cities of Trieste, Rijeka, and Koper. J. Urban Hist. 2020, 1-24. [CrossRef]

101. Mrak, I. Locally based development-tools for identifying opportunities and evaluating port area strategies of Rijeka. Sustainability 2013, 5, 4024-4056. [CrossRef]

102. Marjanić, S. Art intervention in industrial cultural heritage or, how does socially useful art come about? Nar. Umjet. Hrvat. časopis za Etnol. i Folk. 2011, 48, 29-52.

103. Urošević, N. Culture and Sustainable Urban Development: Valuing a Common European Heritage in Croatian Candidates for the ECOC. In Proceedings of the Culture and Growth: Magical Companions or Mutually Exclusive Counterparts, 8th UNEECC Conference Proceedings, Umea, Sweden, 23-24 October 2015; Lundgren, B., Matiu, O., Eds.; Lucian Blaga University of Sibiu Press: Sibiu, Romania, 2015; Volume 7, pp. 127-138.

104. Stipanović, C.; Rudan, E.; Zubović, V. Cultural and creative industries in urban tourism innovation: The example of the city of Rijeka. In Proceedings of the ToSEE-Tourism in Southern and Eastern Europe; University of Rijeka: Opatija, Croatia, 2019; Volume 5, pp. 655-666.

105. Morgan, D.L. Focus Groups. Annu. Rev. Sociol. 1996, 22, 129-152. [CrossRef]

106. Löhr, K.; Weinhardt, M.; Sieber, S. The "World Café" as a Participatory Method for Collecting Qualitative Data. Int. J. Qual. Methods 2020, 19, 1-15. [CrossRef]

107. Acocella, I. The focus groups in social research: Advantages and disadvantages. Qual. Quant. 2012, 46, 1125-1136. [CrossRef]

108. Krippendorff, K. Content Analysis: An Introduction to Its Methodology; Sage: London, UK, 1980.

109. Wickham, H. Tidy data. J. Stat. Softw. 2014, 59, 1-23. [CrossRef]

110. Bengtsson, M. How to plan and perform a qualitative study using content analysis. NursingPlus Open 2016, 2, 8-14. [CrossRef]

111. Thomas, J.; Harden, A. Methods for the thematic synthesis of qualitative research in systematic reviews. BMC Med. Res. Methodol. 2008, 8, 45. [CrossRef] [PubMed]

112. Janesick, V.J. Peer Debriefing. In The Blackwell Encyclopedia of Sociology; John Wiley \& Sons, Ltd.: Oxford, UK, 2015. 
113. Shannon, P.; Markiel, A.; Ozier, O.; Baliga, N.S.; Wang, J.T.; Ramage, D.; Amin, N.; Schwikowski, B.; Ideker, T. Cytoscape: A Software Environment for Integrated Models of Biomolecular Interaction Networks. Genome Res. 2003, 13, $2498-2504$. [CrossRef]

114. Rijeka 2020 The Ship Galeb. Available online: https:/ / rijeka2020.eu/en/about-the-project/buildings-renovation/brod-galeb-2/ (accessed on 21 January 2021).

115. Bullen, P.A.; Love, P.E.D. Adaptive reuse of heritage buildings: Sustaining an icon or eyesore. In Proceedings of the COBRA 2011-Proceedings of RICS Construction and Property Conference 2011, Salford, UK, 12-13 September 2011; pp. 1652-1662.

116. Eisenack, K.; Moser, S.C.; Hoffmann, E.; Klein, R.J.T.; Oberlack, C.; Pechan, A.; Rotter, M.; Termeer, C.J.A.M. Explaining and overcoming barriers to climate change adaptation. Nat. Clim. Chang. 2014, 4, 867-872. [CrossRef]

117. Fatorić, S.; Seekamp, E. Securing the Future of Cultural Heritage by Identifying Barriers to and Strategizing Solutions for Preservation under Changing Climate Conditions. Sustainability 2017, 9, 2143. [CrossRef]

118. Kermani, A.A.; van der Toorn Vrijthoff, W.; Salek, A. The Impact of Planning Reform on Water-Related Heritage Values and on Recalling Collective Maritime Identity of Port Cities: The Case of Rotterdam. In Adaptive Strategies for Water Heritage; Springer International Publishing: Cham, Switzerland, 2020; pp. 344-361.

119. De Medici, S.; Riganti, P.; Viola, S. Circular Economy and the Role of Universities in Urban Regeneration: The Case of Ortigia, Syracuse. Sustainability 2018, 10, 4305. [CrossRef]

120. Gravagnuolo, A.; Angrisano, M.; Girard, L.F. Circular economy strategies in eight historic port cities: Criteria and indicators towards a circular city assessment framework. Sustainability 2019, 11, 3512. [CrossRef]

121. Fusco Girard, L. Toward a Smart Sustainable Development of Port Cities/Areas: The Role of the "Historic Urban Landscape" Approach. Sustainability 2013, 5, 4329-4348. [CrossRef] 